\title{
Penerapan Pembelajaran Berbasis Multikultural dengan Model Kooperatif Time Token untuk Meningkatkan Hasil Belajar dan Keterampilan Sosial Peserta Didik pada Mata Pelajaran Sejarah Kelas XII IPS 1 SMAN 1 Jenggawah Tahun Pelajaran 2016/2017 The Implementation of Multicultural Based Learning with Time Token Cooperative Model to Improve Twelfth Grade IPS 1 Students Learning Achievement and Social Skills on History Subject at SMAN 1 Jenggawah in The 2016/2017 Academic Year
}

\author{
Hajar Riza Asyiyah, Bambang Soepeno, Sumarno \\ Program Studi Pendidikan Sejarah, FKIP, Universitas Jember (UNEJ) \\ Jln. Kalimantan 37, Jember 68121 \\ E-mail:bsoepeno2013@gmail.com
}

Abstrak

Penelitian ini bertujuan untuk menganalisis peningkatan hasil belajar dan keterampilan sosial peserta didik melalui penerapan pembelajaran berbasis multikultural dengan model kooperatif Time Token pada mata pelajaran Sejarah kelas XII IPS 1 SMAN 1 Jenggawah tahun pelajaran 2016/2017. Jenis penelitian ini adalah penelitian tindakan kelas yang terdiri dari 3 siklus dan masing-masing siklus terdiri dari empat tahapan yaitu perencanaan, tindakan, observasi, dan refleksi. Hasil penelitian menunjukkan bahwa terdapat peningkatan hasil belajar peserta didik pada siklus 1 sebesar $71,25 \%$, siklus 2 meningkat sebesar $73,75 \%$, dan siklus 3 meningkat sebesar $81,38 \%$. Hasil keterampilan sosial peserta didik menunjukkan bahwa peningkatan rata-rata keterampilan sosial peserta didik pada siklus 1 sebesar 39,02\%, pada siklus 2 meningkat sebesar $63,05 \%$ dan siklus 3 sebesar $76,66 \%$. Adanya penelitian ini diharapkan dapat dijadikan acuan bagi pendidik dalam pengelolaan proses pembelajaran sejarah yang lebih/ berkualitas untuk meningkatkan hasil pembelajaran sejarah.

Kata Kunci : Pembelajaran Berbasis Multikultural, Model Kooperatif Time Token, Hasil Belajar Peserta Didik, dan Keterampilan Sosial

\section{Abstract}

This research is intended to analyze the improvement of the twelfth grade IPS 1 students' learning achievement and social skill on the history subject trough the implementation of multicultural based learning with cooperative model of Time Token that had been conducted at SMAN 1 Jenggawah in the 2016/2017 academic year. The design of this research is classroom action research that contains three cycles and each cycle contains four steps, those are planning, action, observation and reflection. The results of the research showed that there were some improvements on the students' learning achievement, such as in cycle 1 the average was about 71,25\%, it became 73,75\% in cycle 2 and in the cycle 3 became 81,38\%. Whereas, the students' social skill also showed the improvement, in cycle 1 the average was about $39,02 \%$, it became 63,05\% in cycle 2 and in the cycle 3 became 76,66\%. The results of this research were expected to be the references for the teacher in conducting the more excellent teaching and learning process of history subject to improve the students' learning achievement.

Keywords : Multicultural-based learning, Cooperative model of Time Token, student's learning achievement and social skill.

\section{Pendahuluan}

Indonesia merupakan negara kepulauan yang terdiri dari berbagai kelompok etnis, budaya, suku, dan agama sehingga secara sederhana masyarakat Indonesia dapat disebut sebagai masyarakat multikultural. Masyarakat Indonesia yang plural dilandasi oleh berbagai perbedaan baik horizontal maupun vertikal [3]. Indonesia disebut sebagai negara multikultur karena memiliki ciri keragaman agama, suku, jumlah dan persebaran pulau, bahasa dan sejumlah keragaman lain yang harus dibanggakan. Akan tetapi, tanpa disadari bahwa keragaman tersebut juga menyimpan potensi konflik yang dapat mengancam kehidupan berbangsa dan bernegara. Atas dasar tersebut, maka pendidikan berwawasan multikultural menjadi sangat penting untuk diterapkan dalam proses pendidikan sejak dini. 
Pada Kurikulum Tingkat Satuan Pendidikan (KTSP), satuan pendidikan merupakan pusat pengembangan nilai-nilai budaya dan karakter bangsa sebagai satu kesatuan kegiatan yang terjadi di sekolah. Dalam mengembangkan pendidikan karakter bangsa, kesadaran akan siapa dirinya dan bangsanya adalah bagian yang penting, sehingga dengan adanya kurikulum yang demikian, nilai dan karakter yang dikembangkan pada diri peserta didik akan sangat kokoh dan memiliki dampak dalam kehidupan [1]. Oleh karena itu, nilai-nilai pendidikan budaya dan karakter bangsa yang terdapat pada dalam KTSP dapat diintegrasikan sesuai dengan indikator sekolah, kelas maupun mata pelajaran yang akan dilaksanakan dalam kegiatan pembelajaran.

Pendidikan pada dasarnya adalah proses pembentukan karakter yang dapat diimplementasikan dalam kegiatan pembelajaran. Mata pelajaran Sejarah seringkali dianggap kurang penting bagi sebagian peserta didik. Sejarah dianggap sebagai rangkaian peristiwa masa lalu yang tidak ada relevansinya dengan masa depan. Dalam pembelajaran sejarah, peran penting pembelajaran bukan hanya sebagai proses transfer ide, akan tetapi juga pendewasaan peserta didik untuk memahami identitas, jati diri dan kepribadian bangsa melalui pemahaman terhadap peristiwa sejarah [5]. Oleh karena itu, inovasi pembelajaran sejarah sangat dibutuhkan sehingga dapat memberi makna dan kesan bagi peserta didik yang akan mempunyai banyak manfaat dalam kehidupan berbangsa.

Pembelajaran sejarah yang dilaksanakan di SMAN 1 Jenggawah dapat diketahui oleh peneliti pada saat melakukan kegiatan observasi awal dengan mengikuti proses pembelajaran sejarah secara langsung di kelas. Terdapat 36 peserta didik di kelas XII IPS 1 dengan memiliki latar belakang yang berbeda, sehingga pendidik terkadang mengalami kesulitan untuk memahami karakteristik peserta didiknya. Mayoritas peserta didik di kelas XII IPS 1 terdiri dari 20 peserta didik dari suku Madura, 10 peserta didik dari suku Jawa, 5 peserta didik merupakan percampuran dari suku Jawa-Madura dan 4 orang peserta didik berasal dari suku Sunda. Peserta didik yang terdiri dari 23 peserta didik laki-laki dan 13 peserta didik perempuan ini memiliki latar belakang agama yang mayoritas memeluk agama Islam sebanyak 35 peserta didik dan 1 peserta didik memeluk agama Nasrani. Apabila dilihat dari konteks sosial secara ekonomi, peserta didik kelas XII IPS 1 memiliki keberagaman latar belakang keluarga dengan keterangan 10 peserta didik yang orang tuanya bekerja sebagai PNS, 5 peserta didik yang orang tuanya bekerja sebagai sebagai non PNS, 5 peserta didik yang orang tuanya bekerja sebagai swasta, dan 16 peserta didik yang orang tuanya bekerja sebagai buruh.

Berdasarkan hasil observasi awal yang dilakukan oleh peneliti, diketahui bahwa keterampilan sosial peserta didik kelas XII IPS 1 pada saat pembelajaran sejarah dinyatakan pada kriteria kurang. Hasil observasi awal keterampilan sosial peserta didik tersebut meliputi: (1) berkomunikasi baik dengan teman sebesar $31,25 \%$; (2) saling menghargai antar sesama teman sebesar 33,33\%; (3) menyalurkan dan menerima pendapat saat diskusi sebesar $32,63 \%$; (4) memecahkan masalah saat diskusi sebesar
31,94\%; dan (5) bertindak disiplin selama kegiatan pembelajaran sebesar $34,72 \%$. Dilihat dari hasil observasi tersebut, kurangnya keterampilan sosial peserta didik disebabkan karena pendidik masih menerapkan metode ceramah sehingga kurang memahami karakteristik peserta didik di kelas XII IPS 1 yang memiliki latar belakang berbeda.

Berdasarkan hasil studi dokumentasi yang dilakukan oleh peneliti di kelas XII IPS 1 SMAN 1 Jenggawah, diketahui rata-rata hasil belajar kelas XII IPS 1 lebih rendah dibandingkan dengan kelas lainnya. Rata-rata hasil belajar peserta didik diambil dari hasil nilai ulangan kenaikan kelas XII, yaitu sebagai berikut.

Tabel 1. Rata-rata Hasil Belajar Peserta Didik Kelas XI IPS SMAN 1 Jenggawah pada Mata Pelajaran Sejarah Semester Genap Tahun Pelajaran 2015/2016

\begin{tabular}{|c|l|}
\hline \multicolumn{2}{|c|}{ Rata-rata Hasil Belajar Peserta Didik } \\
\hline XI IPS 1 & \multicolumn{1}{c|}{ XI IPS 2 } \\
\hline \hline nilai $=70,7$ & nilai $=76,8$ \\
$\sum$ peserta didik $=36$ & $\sum$ peserta didik $=39$ \\
$\sum$ tuntas $=11$ & $\sum$ tuntas $=27$ \\
$\sum$ tidak tuntas $=25$ & $\sum$ tidak tuntas $=12$ \\
\hline
\end{tabular}

Sumber: Hasil studi dokumentasi

Pada tabel 1. menunjukkan bahwa rata-rata hasil belajar peserta didik pada mata pelajaran Sejarah di kelas XI IPS 1 lebih rendah dibandingkan dengan kelas XI IPS 2. Rata-rata nilai tersebut diambil dari nilai hasil ujian kenaikan kelas peserta didik. Rata-rata hasil belajar peserta didik kelas XI IPS 1 yaitu 70,7 dari 36 siswa yang terdiri dari 23 siswa laki-laki dan 13 siswa perempuan. Nilai tersebut menunjukkan bahwa hasil belajar peserta didik kelas XI IPS 1 yang sekarang sudah naik dikelas XII belum mencapai Kriteria Ketuntasan Maksimal (KKM) yang ditetapkan oleh sekolah yaitu 75 .

Peneliti melakukan kegiatan observasi, wawancara dan studi dokumen di kelas XII IPS 1 SMAN 1 Jenggawah dengan hasil yang menyatakan bahwa kelas tersebut membutuhkan upaya khusus untuk meningkatkan hasil belajar dan keterampilan sosial peserta didik. Sebagai upaya untuk mengatasi permasalahan pembelajaran sejarah di kelas XII IPS 1, peneliti berusaha memberikan solusi dengan menerapkan strategi dan model pembelajaran yang inovatif dalam proses pembelajaran sejarah.

Strategi pembelajaran yang akan diterapkan yaitu pembelajaran berbasis multikultural dengan model pembelajaran kooperatif Time Token. Pendidikan berwawasan multikultural ini memang sangat penting diterapakan di kelas XII IPS 1, karena strategi ini memiliki keutamaan-keutamaan antara lain: (1) memberikan terobosan baru dalam pembelajaran yang mampu meningkatkan empati dan mengurangi prasangka peserta didik sehingga tercipta manusia (warga negara) antar budaya yang mampu menyelesaikan konflik dengan tanpa kekerasan (nonviolent); (2) menerapkan pendekatan dan strategi pembelajaran yang potensial dalam mengedepankan proses interaksi sosial dan memiliki kandungan afeksi yang kuat; (3) model pembelajaran multikultural membantu pendidik dalam mengelola proses 
pembelajaran menjadi lebih efisien dan efektif, terutama memberikan kemampuan peserta didik dalam membangun kolaboratif dan memiliki komitmen nilai yang tinggi dalam kehidupan masyarakat yang majemuk; (4) memberikan kontribusi bagi bangsa Indonesia dalam penyelesaian dan mengelola konflik yang bernuansa SARA yang timbul di masyarakat dengan cara meningkatkan empati dan mengurangi prasangka [2].

Model pembelajaran kooperatif merupakan pembelajaran berbasis sosial. Model pembelajaran kooperatif dikembangkan untuk mencapai hasil belajar berupa prestasi akademik, toleransi, menerima keberagaman, dan pengembangan keterampilan sosial [4]. Model kooperatif Time Token menjadikan aktivitas peserta didik menjadi titik perhatian utama, sehingga peserta didik selalu dilibatkan secara aktif dalam proses pembelajaran. Model pembelajaran ini bertujuan untuk melatih dan mengembangkan keterampilan sosial agar peserta didik tidak mendominasi pembicaraan pada saat kegiatan pembelajaran.

Berdasarkan pemaparan permasalahan dalam proses pembelajaran sejarah di kelas XII IPS 1, peneliti akan menerapkan strategi pembelajaran berbasis multikultural dengan model pembelajaran kooperatif Time Token. Model kooperatif Time Token dirasa sangat cocok dipadukan dengan strategi pembelajaran berbasis multikultural karena saling memiliki tujuan untuk mengembangkan keterampilan sosial peserta didik di dalam kelas. Melalui penerapan pembelajaran berbasis multikultural dengan model koperatif Time Token diharapkan dapat meningkatkan pemahaman peserta didik terkait tentang pembelajaran sejarah. Atas dasar pertimbangan inilah peneliti tertarik melakukan Penelitian Tindakan Kelas dengan judul "Penerapan Pembelajaran Berbasis Multikultural dengan Model Kooperatif Time Token untuk Meningkatkan Hasil Belajar dan Keterampilan Sosial Peserta Didik pada Mata Pelajaran Sejarah Kelas XII IPS 1 SMAN 1 Jenggawah Tahun Pelajaran 2016/2017".

\section{Metode Penelitian}

Subyek dalam penelitian ini adalah peserta didik di kelas XII IPS 1 SMAN 1 Jenggawah yang berjumlah 36 siswa, yang terdiri dari 13 siswa perempuan dan 23 siswa laki-laki. Penelitian ini menggunakan penelitian tindakan kelas. Desain penelitian ini menggunakan desain penelitian model Hopkins. Di dalam model penelitian tindakan kelas terdapat empat komponen pokok yaitu, perencanaan (planning), tindakan (action), pengamatan (observasion, refleksi (reflecting). Metode pengumpulan data yang digunakan dalam penelitian adalah observasi, wawancara, tes dan dokumentasi Pada penelitian ini menggunakan analisis data kualitatif dan analisis data kuantitatif. Analisis data kualitatif digunakan untuk pengumpulan data yang diperoleh dari hasil observasi, wawancara dan dokumentasi. Hasil data kuantitatif berupa tes digunakan untuk mengetahui hasil belajar apakah sesuai dengan yang dicapai atau tidak. Data yang akan dianalisis yaitu hasil observasi keterampilan sosial dan tes hasil belajar peserta didik setelah proses pembelajaran.

Berdasarkan hasil observasi pada saat proses pembelajaran diperoleh informasi-informasi yang selanjutnya dianalisis. Ketuntasan belajar dalam penelitian ini adalah hasil belajar dan keterampilan sosial peserta didik menggunakan standar ketuntasan belajar yang ditetapkan disekolah. Ketuntasan hasil belajar dalam penelitian ini dikatakan tuntas apabila kelas tersebut mendapatkan nilai rata-rata klasikal $\geq 75 \%$ dari skor maksimal 100\%. Sedangkan ketuntasan keterampilan sosial peserta didik dinyatakan berhasil apabila kriteria keterampilan sosial peserta didik memperoleh kriteria baik dengan perolehan skor $70 \% \leq \mathrm{B} \leq 79 \%$ diukur dari indikator: (1) berkomunikasi baik dengan teman; (2) saling menghargai antar sesama teman; (3) dapat menyalurkan dan menerima pendapat; (4) dapat memecahkan masalah saat diskusi; dan (5) bertindak disiplin selama kegiatan pembelajaran.

\section{Hasil dan Pembahasan}

1. Peningkatan Hasil Belajar Peserta Didik Kelas XII IPS 1 SMAN 1 Jenggawah melalui Penerapan Pembelajaran Berbasis Multikultural dengan Model Kooperatif Time Token

Peningkatan hasil belajar peserta didik pada siklus 1 , siklus 2 dan siklus 3 telah diperoleh dari post test yang dilaksanakan disetiap akhir siklus. Aspek kognitif peserta didik diukur melalui post test yang dilaksanakan disetiap akhir siklus. Hasil belajar peserta didik aspek kognitif pada siklus 1,2 dan 3 dapat dilihat pada tabel berikut.

Tabel 2. Peningkatan Hasil Belajar pada Aspek Kognitif Per Siklus

\begin{tabular}{|c|c|c|c|c|c|c|c|}
\hline $\begin{array}{c}\text { Pra } \\
\text { Siklus }\end{array}$ & $\begin{array}{c}\text { Pening } \\
\text { katan }\end{array}$ & $\begin{array}{c}\text { Siklus } \\
1\end{array}$ & $\begin{array}{c}\text { Siklus } \\
2\end{array}$ & $\begin{array}{c}\text { Pening } \\
\text { katan }\end{array}$ & $\begin{array}{c}\text { Siklus } \\
2\end{array}$ & $\begin{array}{c}\text { Siklus } \\
3\end{array}$ & $\begin{array}{c}\text { Pening } \\
\text { katan }\end{array}$ \\
\hline $70,7 \%$ & $0,77 \%$ & $71,25 \%$ & $\begin{array}{c}73,75 \\
\%\end{array}$ & $3,5 \%$ & $73,75 \%$ & $81,38 \%$ & $\begin{array}{c}10,30 \\
\%\end{array}$ \\
\hline
\end{tabular}

Sumber: Hasil penelitian Siklus 1, Siklus 2 dan Siklus 3 Berdasarkan pada tabel 2. dapat dilihat bahwa hasil belajar peserta didik kelas XII IPS 1 pada aspek kognitif diketahui dari presentase rata-rata hasil belajar setiap siklusnya. Rata-rata hasil belajar peserta didik pada pra siklus menunjukkan angka $70,7 \%$ yang kemudian meningkat sebesar $0,77 \%$ menjadi $71,25 \%$ pada siklus 1 . Pada siklus 2 hasil belajar peserta didik meningkat sebesar $3,5 \%$ menjadi $73,75 \%$, kemudian pada pelaksanaan siklus 3 hasil belajar peserta didik pada aspek kognitif meningkat sebesar $10,3 \%$ sehingga rata-rata hasil belajar peserta didik menjadi $81,38 \%$. Hasil presentase ketuntasan hasil belajar peserta didik pada aspek kognitif disajikan dalam diagram berikut.

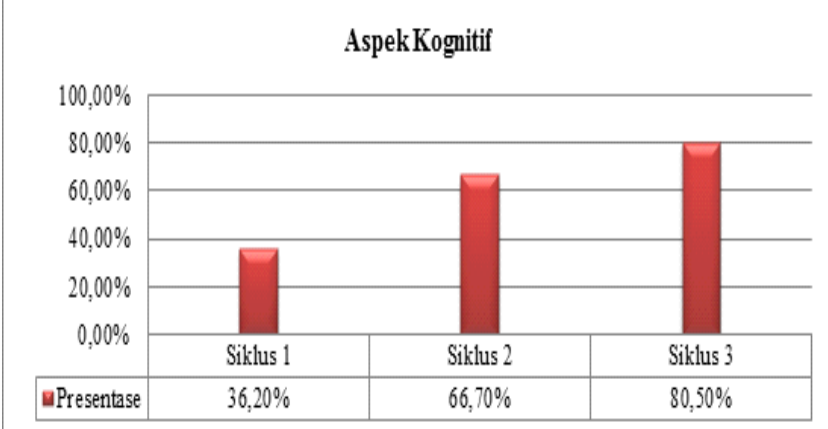


Gambar 1. Diagram peningkatan hasil belajar aspek kognitif (Sumber: Hasil analisis data siklus 1,2 dan 3)

Berdasarkan gambar 1.2 dapat diketahui hasil belajar peserta didik pada aspek kognitif secara klasikal pada siklus 1, 2 dan 3. Presentase ketuntasan hasil belajar peserta didik kelas XII IPS 1 pada siklus 1 diketahui sebesar $36,2 \%$, pada siklus 2 meningkat menjadi $66,7 \%$, dan pada siklus 3 mencapai presentase sebesar $80,5 \%$. Hasil analisis data tersebut menunjukkan bahwa terjadi peningkatan hasil belajar peserta didik pada aspek kognitif melalui penerapan pembelajaran berbasis multikultural dengan model kooperatif Time Token pada pelaksanaan siklus 1, siklus 2 dan siklus 3 .

\section{Peningkatan Keterampilan Sosial Peserta Didik Kelas XII IPS 1 SMAN 1 Jenggawah melalui Penerapan Pembelajaran Berbasis Multikultural dengan Model Kooperatif Time Token}

Peningkatan keterampilan sosial peserta didik kelas XII IPS 1 SMAN 1 Jenggawah melalui penerapan pembelajaran berbasis multikultural dengan model kooperatif Time Token pada pelaksanaan siklus 1, siklus 2 dan siklus 3 dapat dilihat dari perolehan hasil pada setiap indikator keterampilan sosial. Peningkatan keterampilan sosial peserta didik pada pra siklus sampai pelaksanaan siklus 1, siklus 2 dan siklus 3 juga disajikan pada tabel berikut.

Tabel 3. Peningkatan Keterampilan Sosial Pra Siklus, Siklus 1, 2 dan 3

\begin{tabular}{|c|c|c|c|c|c|c|c|}
\hline $\begin{array}{c}\text { Pra } \\
\text { Siklus }\end{array}$ & $\begin{array}{c}\text { Pening } \\
\text { katan }\end{array}$ & $\begin{array}{c}\text { Siklus } \\
1\end{array}$ & $\begin{array}{c}\text { Siklus } \\
2\end{array}$ & $\begin{array}{c}\text { Pening } \\
\text { katan }\end{array}$ & $\begin{array}{c}\text { Siklus } \\
2\end{array}$ & $\begin{array}{c}\text { Siklus } \\
3\end{array}$ & $\begin{array}{c}\text { Pening } \\
\text { katan }\end{array}$ \\
\hline $\begin{array}{c}32,77 \\
\%\end{array}$ & $6,25 \%$ & $\begin{array}{c}39,02 \\
\%\end{array}$ & $\begin{array}{c}63,05 \\
\%\end{array}$ & $24,03 \%$ & $\begin{array}{c}63,05 \\
\%\end{array}$ & $\begin{array}{c}76,66 \\
\%\end{array}$ & $13,61 \%$ \\
\hline
\end{tabular}

Peningkatan keterampilan sosial peserta didik juga disajikan pada diagram berikut.

Persentase Keterampilan Sosial Peserta Didik

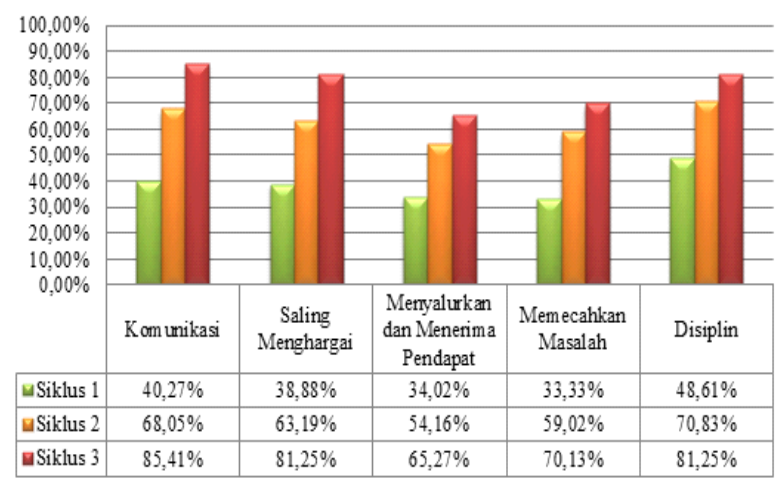

Gambar 2. Diagram Presentase Keterampilan Sosial Peserta Didik Siklus 1, 2 dan 3 (Sumber: Hasil analisis data siklus 1, 2 dan 3)

Pada diagram 1.3 tersebut dapat diketahui bahwa keterampilan sosial peserta didik mengalami peningkatan dari siklus 1, siklus 2 dan siklus 3. Presentase keterampilan sosial peserta didik dalam indikator komunikasi pada siklus 1 sebesar 40,27\%, pada siklus 2 meningkat 27,78\% menjadi $68,05 \%$, dan pada siklus 3 meningkat sebesar $17,36 \%$ menjadi $85,41 \%$. Presentase keterampilan sosial peserta didik dalam indikator saling menghargai antar sesama teman pada siklus 1 sebesar $38,88 \%$, pada siklus 2 meningkat sebesar $24,31 \%$ menjadi $63,19 \%$, dan pada siklus 3 meningkat sebesar $18,06 \%$ menjadi $81,25 \%$. Presentase keterampilan sosial peserta didik dalam indikator menyalurkan dan menerima pendapat pada siklus 1 sebesar 34,02\%, pada siklus 2 meningkat sebesar $20,14 \%$ menjadi $54,16 \%$, dan pada siklus 3 meningkat sebesar $11,11 \%$ menjadi $65,27 \%$. Presentase keterampilan sosial peserta didik memecahkan masalah saat diskusi pada siklus 1 sebesar 33,33\%, pada siklus 2 meningkat sebesar 25,69\% menjadi $59,02 \%$, dan pada siklus 3 meningkat sebesar $11,11 \%$ menjadi $70,13 \%$. Presentase keterampilan sosial peserta didik bertindak disiplin selama kegiatan pembelajaran pada siklus 1 sebesar $48,61 \%$, pada siklus 2 meningkat sebesar $22,22 \%$ menjadi $70,83 \%$, pada siklus 3 meningkat sebesar $10,42 \%$ menjadi $81,25 \%$.

Berdasarkan pada gambar 2. menunjukkan hasil observasi langsung pada pra siklus sampai pelaksanaan siklus 1 , siklus 2 dan siklus 3 dapat disimpulkan bahwa penerapan pembelajaran berbasis multikultural dengan model kooperatif Time Token dapat meningkatkan keterampilan sosial peserta didik kelas XII IPS 1 SMAN 1 Jenggawah pada pembelajaran sejarah.

\section{Kesimpulan dan Saran}

Berdasarkan rumusan masalah yang telah dirumusakan oleh peneliti tentang peningkatan hasil belajar dan keterampilan sosial peserta didik kelas XII IPS 1 SMAN 1 Jenggawah tahun pelajaran 2016/2017 melalui penerapan pembelajaran berbasis multiklutural dengan model kooperatif Time Token pada pada mata pelajaran Sejarah, maka dapat disimpulkan sebagai berikut.

Penerapan pembelajaran berbasis multiklutural dengan model kooepratif Time Token dapat meningkatkan hasil belajar peserta didik pada mata pelajaran Sejarah di kelas XII IPS 1 SMAN/1 Jenggawah tahun pelajaran 2016/2017. Hasil belajar peserta didik diukur melalui tes pada aspek kognitif yang dilaksanakan pada setiap akhir siklus. Presentase perolehan hasil belajar peserta didik pada pra siklus sebesar 30,56\%, pada siklus 1 meningkat sebesar $5,64 \%$ menjadi $36,2 \%$ dengan rata-rata sebesar $71,25 \%$, selanjutnya pada siklus 2 meningkat sebesar $30,5 \%$ menjadi $66,7 \%$ dengan rata-rata sebesar $73,75 \%$, dan pada siklus 3 meningkat sebesar $13,8 \%$ menjadi $80,5 \%$ dengan rata-rata sebesar $81,38 \%$. Berdasarkan hasil observasi langsung pada pelaksanaan siklus 1 , siklus 2 dan siklus 3 dapat disimpulkan bahwa penerapan pembelajaran berbasis multiklutural dengan model kooperatif Time Token dapat meningkatkan hasil belajar (aspek kognitif) peserta didik kelas XII IPS 1 SMAN 1 Jenggawah.

Penerapan pembelajaran berbasis multiklutural dengan model kooepratif Time Token dapat meningkatkan keterampilan sosial peserta didik pada mata pelajaran Sejarah di kelas XII IPS 1 SMAN 1 Jenggawah tahun pelajaran 2016/2017. Keterampilan sosial peserta didik diukur melalui observasi langsung selama proses pembelajaran pada siklus 1, siklus 2 dan siklus 3. Indikator keterampilan sosial yaitu: (1) komunikasi; (2) saling menghargai; (3) menyalurkan dan menerima pendapat; (4) 
memecahkan masalah saat diskusi; dan (5) bertindak disiplin. Presentase keterampilan sosial peserta didik dalam indikator berkomunikasi baik dengan teman pada siklus 1 sebesar 40,27\%, pada siklus 2 meningkat $27,78 \%$ menjadi $68,05 \%$, dan pada siklus 3 meningkat sebesar 17,36\% menjadi 85,41\%. Presentase keterampilan sosial peserta didik dalam indikator saling menghargai antar sesama teman pada siklus 1 sebesar $38,88 \%$, pada siklus 2 meningkat sebesar $24,31 \%$ menjadi $63,19 \%$, dan pada siklus 3 meningkat sebesar $18,06 \%$ menjadi $81,25 \%$. Presentase keterampilan sosial peserta didik dalam indikator menyalurkan dan menerima pendapat pada siklus 1 sebesar 34,02\%, pada siklus 2 meningkat sebesar 20,14\% menjadi 54,16\%, dan pada siklus 3 meningkat sebesar 11,11\% menjadi 65,27\%. Presentase keterampilan sosial peserta didik memecahkan masalah saat diskusi pada siklus 1 sebesar 33,33\%, pada siklus 2 meningkat sebesar 25,69\% menjadi 59,02\%, dan pada siklus 3 meningkat sebesar $11,11 \%$ menjadi $70,13 \%$. Presentase keterampilan sosial peserta didik bertindak disiplin selama kegiatan pembelajaran pada siklus 1 sebesar $48,61 \%$, pada siklus 2 meningkat sebesar $22,22 \%$ menjadi $70,83 \%$, pada siklus 3 meningkat sebesar $10,42 \%$ menjadi $81,25 \%$. Berdasarkan hasil observasi langsung pada pelaksanaan siklus 1 , siklus 2 dan siklus 3 dapat disimpulkan bahwa penerapan pembelajaran berbasis multikultural dengan model kooperatif Time Token dapat meningkatkan keterampilan sosial peserta didik kelas XII IPS 1 SMAN 1 Jenggawah.

Berdasarkan hasil penelitian tentang penerapan pembelajaran berbasis multikultural dengan model kooperatif Time Token untuk meningkatkan hasil belajar dan keterampilan sosial peserta didik pada mata pelajaran Sejarah kelas XII IPS 1 SMAN 1 Jenggawah semester gasal tahun pelajaran 2016/2017 maka peneliti memberikan saran sebagai berikut.

a. Bagi pendidik. Penerapan pembelajaran berbasis multikultural dengan model kooperatif Time Token sebaiknya dapat digunakan sebagai alternatif untuk meningkatkan kualitas pembelajaran sejarah.

b. Bagi Peserta Didik. Penerapan pembelajaran berbasis multikultural dengan model kooperatif Time Token sebaiknya dapat menumbuhkan sikap multikultural dalam kehidupan bermasyarakat dan memotivasi peserta didik dalam proses pembelajaran.

c. Bagi Sekolah. Hasil penelitian dari penerapan pembelajaran berbasis multikultural dengan model kooperatif Time Token sebaiknya digunakan sebagai masukan untuk upaya peningkatan mutu dan kualitas pembelajaran.

d. Bagi Peneliti Lain. Hasil penelitian dari penerapan pembelajaran berbasis multikultural dengan model kooperatif Time Token sebaiknya dapat dijadikan sumber referensi dan dapat dikembangkan lagi.

e. Bagi Pendidikan. Hasil penelitian dari penerapan pembelajaran berbasis multikultural dengan model kooperatif Time Token sebagai sumbangsih dalam perkembangan ilmu pengetahuan.

\section{Ucapan Terimakasih}

Ucapan terimakasih yang sebesar-besarnya disampaikan kepada dosen pembimbing yang telah meluangkan waktu, memberikan bimbingan dan saran dengan penuh kesabaran demi terselesainya jurnal ini. Penulis juga mengucapkan terimakasih kepada Kepala SMAN 1 Jenggawah yang telah memberikan izin untuk pelaksanaan penelitian tenaga pendidik mata pelajaran sejarah yang telah membantu pelaksanaan penelitian ini. Penulis juga mengucapkan terimakasih kepada teman-teman yang telah mebantu penulis dalam melakukan observasi pada penelitian ini.

\section{Daftar Pustaka}

[1] Hasan, S.H. 2010. Pengembangan Pendidikan Budaya dan Karakter Bangsa. Kementrian Pendidikan Nasional Badan Penelitian dan Pengembangan Pusat Kurikulum.

[2] Kamdi, W, dkk. 2007. Model-Model Pembelajaran Inovatif. Malang: UM Press.

[3] Sulalah. 2012. Pendidikan Multikultural. Malang: UIN-Maliki Press.

[4] Suprijono, A. 2009. Cooperative Learning. Yogyakarta: Pustaka Pelajar.

Susanto, H. 2014. Seputar Pembelajaran Sejarah. Yogyakarta: Aswaja Pressindo.

\section{西}

